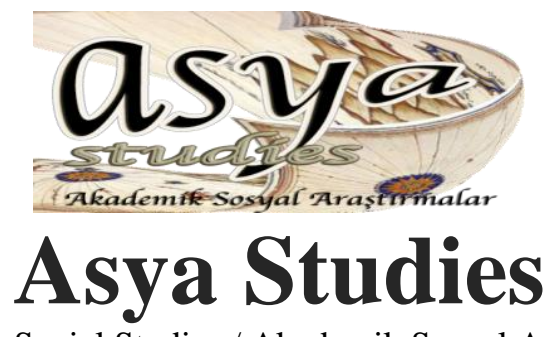

Academic Social Studies / Akademik Sosyal Araştırmalar

Year: 5 - Number: 17 p. 289-298, Autumn 2021

\title{
İlk Adım Türkçeyi Yabancı Dil Olarak Öğrenen Yetişkinler İçin Türkçe-Arapça Çift Alfabeli İlk Okuma-Yazma Kitabı'nın İncelemesi Ed. Prof. Dr. G. Leyla Uzun, Hazırlayanlar: Halil Çağlar, Yeliz Rençber, Ebru Can, Ankara: Ankara Üniversitesi Basımevi
}

The Book Review of İlk Adım Türkçeyi Yabancı Dil Olarak Öğrenen Yetişkinler İçin Türkçe-Arapça Çift Alfabeli Ilk Okuma-Yazma Kitabl

DOI: https://doi.org/10.31455/asya.946405

Kitap İncelemesi / Book Review

\author{
Makale Geliş Tarihi / \\ Article Arrival Date \\ 01.06.2021
}

Makale Kabul Tarihi /
Article Accepted Date
27.07.2021

Makale Yayın Tarihi /

Article Publication Date

29.09.2021

\section{Asya Studies}

Öğr. Gör. Dr. Fikriye Gündüz Jandarma ve Sahil Güvenlik Akademisi, Güvenlik Bilimleri Fakültesi, Yabancı Diller Bölüm

Başkanlığ1-Türkçe Birimi

fikriye1988@hotmail.com

\section{ORCID ID}

Öz

Günümüzde yabancı bir dil bilmenin öğreniciler için gerek eğitim gerekse de iş dünyasında pek çok faydası vardır. Değişen hayat şartları, yabancı dil bilmeyi gerekli kılmıştır. Yabanc1 dil öğrenirken hedef dil ve ana dili arasındaki benzerlikler öğrenicilerin öğrenme isteğini artırmakta, hedef dilin öğrenimini ve öğretimini kolaylaştırmaktadır. Hedef dille ana dili arasında bazı farklılıkların olması olağandır ancak hedef dil ve ana dili arasında alfabe farklılı̆̆ da varsa öğrenicilerin hedef dili öğrenmesi diğer öğrenicilere göre zaman almaktadır. Yabanc1 dil olarak Türkçe öğrenirken öğrenicilerin yaşadığı sıkıntılardan biri alfabe farklılı̆̆ından kaynaklanan okuma ve yazma sorunlarıdır. Ankara Üniversitesi TÖMER'deki öğretim görevlileri tarafından hazırlanmış olan "İlk Adım Türkçeyi Yabancı Dil Olarak Öğrenen Yetişkinler İçin Türkçe-Arapça Çift Alfabeli İlk Okuma-Yazma Kitabı" öğrenicilerin öncelikli olarak okuma yazma sorunlarını çözebilmek amacıyla hazırlanmıştır. Bu çalışmada, "İlk Adım Türkçeyi Yabancı Dil Olarak Öğrenen Yetişkinler İçin Türkçe-Arapça Çift Alfabeli İlk Okuma-Yazma Kitabı" incelenerek tanıtılmıştır. Çalışmada nitel araştırma yöntemlerinden doküman analizi tekniği kullanılmıştır. Çalışmada tanıtılan kitap Suriyeli öğrenicilerin Türkçe öğrenme ihtiyacına yönelik olarak hazırlanmışıır. Kitabın öncelikli amacı Suriyeli öğrenicilerin okuma ve yazma becerilerini geliştirmektir. Ancak kitapta dört temel dil becerisini geliştirmeyi amaçlayan etkinlikler de yer almaktadır. Kitabın CEFR (2020)'de yer alan A1 öncesi ve A1 seviyelerindeki kazanımlarla uyumlu olarak hazırlanmış olduğu, görsellerle desteklendiği, Türkçe ve Arapça iki dilli olarak hazırlandığı tespit edilmiştir.

Anahtar Kelimeler: Ankara Üniversitesi TÖMER, Kitap Tanıtımı, CEFR (2020)

\section{Abstract}

Today, speaking a foreign language has many benefits for learners, both in education and the business world. Changing life conditions made it necessary to speak a foreign language. While learning a foreign language, the similarities between the target language and the native language increase the learning desire of the learners. It is normal to have some differences between the target language and the native language, but if there is a difference in the alphabet between the target language and the native language, it takes time for learners to learn the target language. One of the difficulties experienced by the learners while learning Turkish as a foreign language is the problem of reading and writing caused by the alphabet difference. "İlk Adım Türkçeyi Yabancı Dil Olarak Öğrenen Yetişsinler İ̧̧in Türkçe-Arapça Cift Alfabeli İlk Okuma-Yazma Kitabı" by Ankara University TÖMER was prepared for this need of the learners. In this study, "Ilk Adım Türkçeyi Yabancı Dil Olarak Öğrenen Yetișkinler İçin Türkçe-Arapça Cift Alfabeli İlk Okuma-Yazma Kitabı" was reviewed. Document analysis technique, one of the qualitative research methods, is used in this study. The book reviewed in this study has been prepared for the needs of Syrian learners who learn Turkish. The primary purpose of the book is to improve the reading and writing skills of Syrian learners. However, the book also includes activities aimed at improving the four basic language skills. It has been determined that the book has been prepared in accordance with the pre-Al and Al levels in the CEFR (2020), supported by visuals, and prepared in Turkish and Arabic bilingually.

Keywords: Ankara University TÖMER, Book Review, CEFR (2020)

\section{Citation Information/Kaynakça Bilgisi}

Gündüz, F. (2021). İlk Adım Türkçeyi Yabancı Dil Olarak Öğrenen Yetişkinler İçin Türkçe-Arapça Çift Alfabeli İlk Okuma-Yazma Kitabı'nın İncelemesi Ed. Prof. Dr. G. Leyla Uzun, Hazırlayanlar: Halil Çağlar, Yeliz Rençber, Ebru Can, Ankara: Ankara Üniversitesi Basımevi. Asya Studies-Academic Social Studies / Akademik Sosyal Araştırmalar, 5(17), 289-298. 


\section{GİRIŞ}

Ankara Üniversitesinin Dil ve Tarih-Coğrafya Fakültesi Dilbilim bölümünde öğretim üyesi Prof. Dr. G. Leyla Uzun'un editörlüğünde hazırlanan “İlk Adım Türkçeyi Yabancı Dil Olarak Öğrenen Yetişkinler İçin Türkçe-Arapça Çift Alfabeli İlk Okuma-Yazma Kitabı” adlı çalışma Suriye’de yaşanan savaş sonrasında Türkiye'ye sığınan Suriyeli öğrenicilerin Türkçe öğrenme ihtiyacına yöneliktir.

22 Ocak 2021'de basılmış olan kitap, Türkçe ve Arapça olmak üzere iki bölümden oluşmaktadır. Kitabın birinci bölümü Türkçe ve 136 sayfa olarak hazırlanmıştır. Adı geçen çalışmanın ikinci bölümü ise aynı ünitelerin Arapça yazılmasıyla oluşturulmuştur. Kitabın Türkçe bölümü öğretim görevlisi Halil Çağlar, Yeliz Rençber ve Ebru Can tarafından hazırlanmıştır. Bu bölümün grafik-dizgi ve kapak tasarımı Zuhal Akın'a aittir. Tema kapak çizimlerini ise Serdar Südor yapmıştır. Kitabın Arapça bölümü, Prof. Dr. Gülsün Leyla Uzun'un editörlüğünde Dr. Gülhan Türk tarafından 136 sayfa olarak hazırlanmıştır. Arapça bölümünün Grafik-Dizgi ve Kapak Tasarımını Zuhal Akın, tema kapak çizimlerini ise yine Serdar Südor yapmıştır.

Eser; yazar listesi, ön söz ve içindekiler bölümü ile başlamaktadır. Ön sözde, Ankara Üniversitesi TÖMER'in 1984 yılında kurulmasıyla birlikte "Dezavantajlı Gruplara Yönelik Sosyal Politikalara" katkıda bulunmayı ilke edindiği, mültecilerin ya da Türkiye'de geçici koruma altına alınmış kişilerin bulundukları toplum içinde kendilerini açık ve net olarak ifade edebilme yeterliğini kazanmış bireyler olmasına katkı sağlamayı hedeflediği belirtilmiştir. Ankara Üniversitesi TÖMER'in "Geçici Koruma Altındaki Suriyelilere" yönelik projelerde pek çok Suriyeli vatandaşa okuryazarlık kazandırmayı amaçladıkları, bu çalışmalar sonucunda Ankara Üniversitesi TÖMER'in elde ettiği birikimi kullanarak adı geçen kitabın hazırlandığı belirtilmiştir (Uzun, 2021:3).

“İlk Adım Türkçeyi Yabancı Dil Olarak Öğrenen Yetişkinler İçin Türkçe-Arapça Çift Alfabeli İlk Okuma-Yazma Kitabı” bu çalışmada doküman analizi yöntemi ile incelenmiştir. Doküman analizi, yazılı belgeleri sistematik bir şekilde incelemek için kullanılmakta olan nitel bir araştırma yöntemidir (Wach, 2013; Akt. Kıral, 2020). Doküman analizi, basılı ve elektronik materyalleri incelemek ve değerlendirmek için kullanılmaktadır. Nitel araştırmalarda kullanılan diğer yöntemlerde olduğu gibi doküman analizinde de bir anlam çıkarmak, konu hakkında bir anlayış oluşturmak, deneysel bilginin geliştirilmesi için verilerin incelenmesi ve yorumlanması gerekmektedir (Corbin ve Strauss, 2008; Akt. Kiral, 2020).

İncelenen kitapta iki özellik dikkat çekmektedir. Bu özelliklerden birincisi, kitabın iki dilli olmasıdır. Alan yazında iki dilli kitaplar bulunmaktadır. Bu kitaplara Flores (1964)'1n İspanyolcaİngilizce iki dilli hikâye kitabı, Appelbaum (2011)'un İtalyanca-İngilizce şiirlerden, hikâyelerden, felsefi ve tarihi metinlerden oluşan kitapları örnek olarak verilebilir. Ancak söz konusu kitaplar okuma becerisinin geliştirilmesine yönelik olarak hazırlanmış, diğer becerilerin geliştirilmesine yönelik etkinlikler söz konusu çalışmalarda yer almamıştır. Yabancı dil olarak Türkçe öğretiminde hedef dilin yardımcı bir dil vasıtasıyla kullanımı Yeni İstanbul Uluslararası Öğrenciler için Türkçe ders kitaplarında görülmektedir. Ancak Yeni İstanbul Uluslararası Öğrenciler için Türkçe ders kitaplarında bu durum sadece dil bilgisi terimlerinin verilmesinde ve dil bilgisine yönelik bazı açıklamalarda kullanılmıştır. Örneğin, adı geçen ders kitabının A1 seviyesinde "Belirtisiz İsim Tamlaması" konusunda şu şekilde bir açıklama görülmektedir: "Tamlayanı yalın hâlde (eksiz) bulunan, tamlananı 3. tekil kişi iyelik ekini (-I/sI) alan tamlamalardır. Bu tamlama bir nesnenin türünü ve adını gösterir. These compound nouns indicate either the name of an object (Boğaz Köprüsü (The Bosphorus Bridge)) or the sort, type or category to which an object belongs (mercimek çorbası (Lentil Soup) or diş firçası (toothbrush). As possession is not involved, the determiner does not take any possesive suffixes. However, unlike English, the determined noun is supposed to take -I/sI suffix to form an indefinite compound noun (Bölükbaş ve Yılmaz, 2020: 108). Alan yazında iki dilli kitaplara İngilizce-Türkçe dil bilgisi anlatımlarının olduğu, Türk öğrenicilerin İngilizce dil bilgisi yapılarını anlamaları için hazırlanmış İngilizce dil bilgisi kitapları da örnek olarak verilebilir (Buz, 2002; Karakuzu ve Takkaç, 2011 gibi.)

Kitapta dikkat çeken ikinci özellik ise öğrenicilerin Latin alfabesi ile okuma-yazma öğrenirken başlangıçta yaptıkları çizgi çalışmalarına kitapta bolca yer vermesidir. Bu yönüyle kitabın alan yazın için önemli olduğu görülmektedir.

“İlk Adım Türkçeyi Yabancı Dil Olarak Öğrenen Yetişkinler İçin Türkçe-Arapça Çift Alfabeli İlk Okuma-Yazma Kitabı” adlı kitap on altı üniteden oluşmaktadır. Kitapta öncelikli olarak öğrenicilerin Latin harflerini öğrenmeleri amaçlanmıştır. Yabancı dil olarak Türkçe öğretiminde Çiftçi ve Demirci (2019), Şengül (2014) gibi çalışmalarda da belirtildiği gibi alfabe farklılığından kaynaklanan bazı 
İlk Adım Türkçeyi Yabancı Dil Olarak Öğrenen Yetişkinler Iç̧in Türkçe-Arapça Çift Alfabeli İlk Okuma-Yazma

Kitabı'nın İncelemesi Ed. Prof. Dr. G. Leyla Uzun, Hazırlayanlar: Halil Çă̆lar, Yeliz Rençber, Ebru Can,

Ankara: Ankara Üniversitesi Basımevi

sorunlar yaşanabilmektedir. Kitabın bu anlamda alandaki önemli bir soruna dikkat çektiği, on ikinci üniteye kadar harflerin öğretimine ağırlık verdiği görülmektedir. Kitapta yer alan her ünite dinleme çalışmasıyla başlamaktadır. Alan yazında Altunkaya (2018), Kurudayığlu ve Zorpuzan (2018), Melanlığlu (2016) gibi çalışmalarda yabancı dil olarak Türkçe öğretiminde dinleme becerisinin öneminden ve dinleme çalışmaları etkinliklerinden bahsedilmiştir. İncelenen kitapta da her üniteye dinleme becerisiyle başlanması; dinleme becerisine önem verildiğini, Suriyeli öğrenicilere başlangıçta dinleme becerisiyle konunun sezdirilmeye çalışıldığı ve öğrenicilerin daha fazla dinleme etkinliği ile karşılaştırılmak istendiği görülmektedir. Kitapta yer alan ünitelerin etkinlik sayıları, üniteye göre değişmektedir. Ünitelerde yer alan etkinlikler şu şekilde gösterilebilir:

Tablo 1: Kitapta Yer Alan Etkinlik Sayısı ve Etkinliklerin Dağılımı ${ }^{1}$

\begin{tabular}{|c|l|c|c|c|c|c|}
\hline Ünite & Ünitenin Adı & $\begin{array}{c}\text { Toplam } \\
\text { Etkinlik } \\
\text { Sayısı }\end{array}$ & $\begin{array}{c}\text { Okuma } \\
\text { Etkinliği }\end{array}$ & $\begin{array}{c}\text { Dinleme } \\
\text { Etkinliği }\end{array}$ & $\begin{array}{c}\text { Konuşma } \\
\text { Etkinliği }\end{array}$ & $\begin{array}{c}\text { Yazma } \\
\text { Etkinliği }\end{array}$ \\
\hline 1. Ünite & Merhaba & 28 & 3 & 8 & 4 & 13 \\
\hline 2. Ünite & Ailem & 23 & 4 & 5 & 3 & 11 \\
\hline 3. Ünite & Evim & 26 & 11 & 7 & 1 & 7 \\
\hline 4. Ünite & Sayılar & 14 & 2 & 3 & 2 & 7 \\
\hline 5. Ünite & Sokakta & 25 & 8 & 7 & 1 & 9 \\
\hline 6. Ünite & Nasılsın? & 24 & 8 & 6 & 1 & 9 \\
\hline 7. Ünite & Ne Yiyoruz? Ne & 27 & 9 & 5 & 1 & 12 \\
& İçiyoruz? & & & & & 10 \\
\hline 8. Ünite & Meslekler & 28 & 8 & 9 & 1 & 8 \\
\hline 9. Ünite & Kursta & 26 & 9 & 8 & 1 & 10 \\
\hline 10. Ünite & Renkler & 26 & 8 & 7 & 3 & 9 \\
\hline 11. Ünite & Saatler & 22 & 4 & 6 & 3 & 8 \\
\hline 12. Ünite & Günler ve Aylar & 17 & 1 & 5 & 4 & 4 \\
\hline 13. Ünite & Alışveriş & 24 & 5 & 11 & 2 & 4 \\
\hline 14. Ünite & Kıyafetler & 16 & 5 & 5 & 3 & 5 \\
\hline 15. Ünite & Bir Günüm & 18 & 5 & 5 & 2 & 2 \\
\hline 16. Ünite & Boş Zamanım & 18 & 10 & 4 & & \\
\hline
\end{tabular}

Tabloda yer alan etkinliklerin dağılımı Şekil 1'deki grafikte gösterilmiştir:

Şekil 1: Kitaptaki Etkinliklerin Dă̆llımı

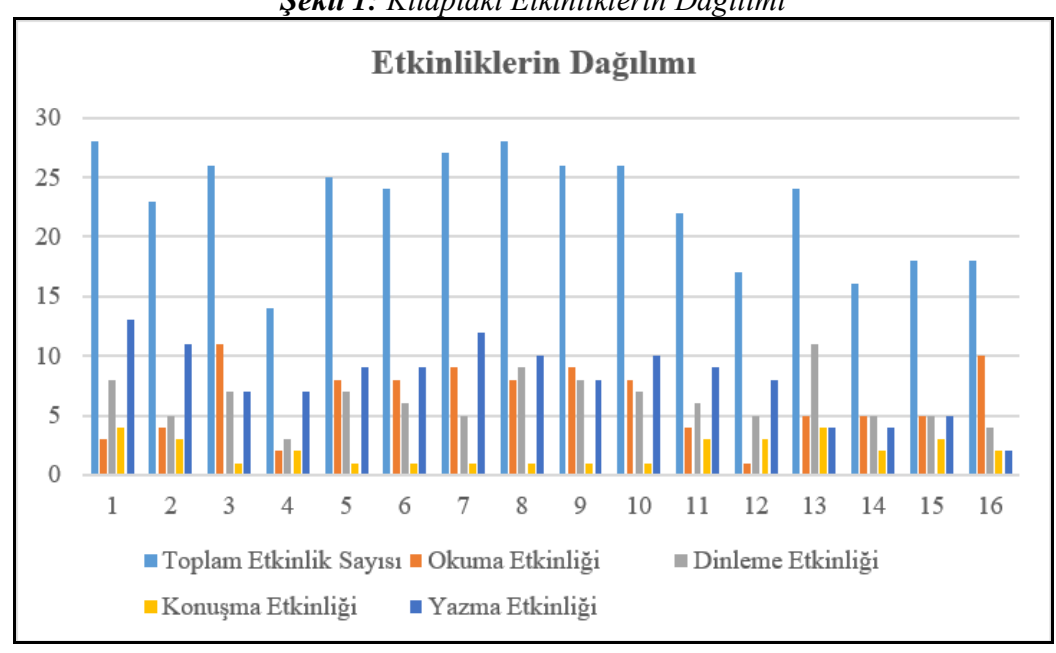

${ }^{1} \mathrm{Bu}$ tabloda etkinliklerin becerilere göre dağılımları etkinliğin birinci amaçları göz önüne alınarak yazılmıştır. Örneğin dinleme etkinliğinin birinci amacı dinlediğini anlama olduğu için dinleme etkinliği olarak hesaplanmış, aynı etkinlikle ilgili konuşma etkinlikleri konuşma etkinliğine dâhil edilmemiştir. Kitapta yer alan harfi ya da sözcüğü bulma etkinlikleri ve eşleştirme etkinlikleri okuma becerisi içerisinde değerlendirilmiștir. 
Kitapta sözlü anlatım ve karşılıklı konuşma olmak üzere iki konuşma türünde, konuşma etkinliği hazırlandığı görülmektedir. Söz konusu konuşma etkinliklerinin iki şekilde tasarlanması CEFR (2020)'de yer alan "Overall oral production" ve "Conversation" bölümlerindeki kazanımlarla da uyumludur. CEFR (2020)'deki kazanımlar şu şekilde belirtilebilir:

Tablo 2: CEFR (2020) Al Öncesi Konuşma Becerisi Yeterlikleri

\begin{tabular}{|c|c|}
\hline Konuşma Becerisi & Kazanımlar \\
\hline Karşılıklı Konuşma & $\begin{array}{l}\text { Basit selamları tanıyabilir. } \\
\text { İnsanları selamlayabilir, adını söyleyebilir ve basit bir } \\
\text { şekilde onlara veda edebilir. }\end{array}$ \\
\hline Sözlü Anlatım & $\begin{array}{l}\text { Kisa, formülsel ifadeler kullanarak kendini tanıtabilir, } \\
\text { günlük rutinler hakkında kisa ifadeler üretebilir. } \\
\text { "Evet", "Hayır", "Affedersiniz", "Lütfen", } \\
\text { "Teşekkürler", "Hayır, teşekkürler", "Üzgünüm" gibi } \\
\text { temel, formüle dayalı ifadeleri anlayabilir ve bu ifadeleri } \\
\text { kullanabilir. }\end{array}$ \\
\hline
\end{tabular}

\section{Kitaptaki Ünitelerin İncelenmesi}

\section{1. Ünite}

Kitabın birinci ünitesi "Merhaba” başıı̆ı̆ı taşımaktadır. Bu ünitede, öğrenicilerin adını yazması ve selamlaşma ifadelerini öğrenmesi amaçlanmıştır. Üçüncü etkinlikten itibaren çizgi çalışmalarına ve E, L, A harflerinin yazımına ağırlık verilmiştir.

\section{2. Ünite}

Kitabın ikinci ünitesinin adı “Ailem”dir. Ünite, dinleme çalışmasıyla başlamaktadır. Dinleme çalışmasını "Yeni Sözcükler” bölümü takip etmekte ve aile üyeleri "Bu kim?” kalıbıyla öğretilmektedir. İkinci ünitede çizgi çalışmalarına devam edilmiş olup $\mathrm{K}, \dot{\mathrm{I}}, \mathrm{N}$ harflerinin öğretimine yer verilmiştir. Bu çalışmaları dinleme etkinliği takip etmiştir. Öğrenicilerin ailelerini tanıtabilmeleri için cümle kalıpları verilmiş, öğrenicilerin ailelerini tanıtmaları istenmiştir.

\section{3. Ünite}

Üçüncü ünite "Evim” başlığını taşımaktadır. Ünite, dinleme etkinliği ile başlamakta ve dinleme etkinliğinin sonrasında öğretilmesi hedeflenen sözcükler yer almaktadır. Bu ünitede $\mathrm{O}, \mathrm{M}$, U harfleri verilmiş olup öğrenicilerin daha önce öğrendikleri harflerle oluşturulan sözcükleri okumaları istenmiştir. Ünitede "Bu, şu, o ne?" kalıbı verilmiş ve resimlerle "Bu ne?" ve "Bu kim?" sorularının eşleştirilmesi amaçlanmıştır. Ünitenin son etkinliği salon ve yatak odasında yer alan eşyaların etkinlikte verilen görsellerle eşleştirilmesidir.

\section{4. Ünite}

Dördüncü ünite "Sayılar" başlığında olup ünite yine bir dinleme etkinliği ile başlamıştır. Dinleme etkinliğinin altında rakamlar verilmiştir. Ünitede "Kaç tane var?" soru kalıbın öğretilmesi amaçlanmıştır. Ünitenin diğer etkinlikleri de görsellerdeki nesnelerin sayabilme, bunları yazılı olarak ifade edebilme ve rakamları tanıyabilme etkinliklerine ayrılmıştır.

\section{5. Ünite}

"Sokakta" başlığını taşıyan beşinci ünite, öğrenicilerin sokakta yürürken görebilecekleri nesnelerin ve yerlerin öğretimini amaçlamıştır. Bu ünitede; burada, şurada, orada yapılarına yer verilmiştir. Ünitede $T$, Ü ve Y harfleri verilmiş, daha önce öğretilen harflerle sözcükler türetilmiştir.

\section{6. Ünite}

Altıncı ünite "Nasılsın?" başlığını taşımaktadır. Ünitede, sıfatların öğretimi amaçlanmıştır. "Nasılsın? ve Bugün hava nasıl?” gibi soru kalıplarıyla bu soru kalıplarının cevaplarına yer verilmiştir. 
İlk Adım Türkçeyi Yabancı Dil Olarak Öğrenen Yetişkinler İçin Türkçe-Arapça Çift Alfabeli İlk Okuma-Yazma

Ünitede Ö, R ve I harflerinin öğretimi gerçekleştirilmiştir. Bu harflerle birlikte sözcükler yazılmış, öğrenicilerin okuma ve yazma becerisini geliştirecek etkinliklere yer verilmiştir.

\section{7. Ünite}

Yedinci ünitenin başlı̆̆ "Ne yiyoruz? Ne içiyoruz?" dur. Ünite, daha önceki ünitelerde olduğu gibi dinleme etkinliği ile başlamıştır. Ünitede "Ne yiyorsun?" "Ne içiyorsun?" "Ne istiyorsun?" soru kalıplarına yönelik sözcüklerin öğretimi amaçlanmıştır. Ünitede D, S ve B harfleri öğretilmiş, bu harflerin tanınmasını sağlayacak sözcüklerin yazımına ve harflerin birleşimiyle ortaya çıkan sözcükleri okuma çalışmalarına yer verilmiştir. Ünitede yiyecek ve içecek kavram alanlarının ayrımına yer verilmiş, öğrenicilerin bu kavram alanında yer alan temel sözcükleri tanıması istenmiştir. Söz konusu durumun sebebi Barın (2003)'ın da çalışmasında belirttiği temel söz varlığının öğrenicilere kazandırması ile ilgilidir. Ünitede yer verilen yiyecek ve içecek adları temel söz varlığının içerisinde değerlendirilen günlük hayatla ilgili sözcüklerdir.

\section{8. Ünite}

Sekizinci ünite "Meslekler" başlığını taşımaktadır. Ünitede yer alan yeni sözcükler, meslek adları şeklinde verilmiştir. Ünitede "Siz ne iş yapıyorsunuz?" ve "O ne iş yapıyor?" soru kalıplarının öğretimi amaçlanmıştır. Ünitenin ikinci etkinliği alfabede yer alan harflerin verildiği bir listeden oluşmaktadır. Öğretimi gerçekleştirilmeyen harfler kırmızı renk ile gösterilmiştir. Öğretimi gerçekleştirilen harflerin ise yanına görseller eklenmiştir. Öğrenicilerden kutuda daha önce verilen harfleri görsellerle eşleştirmeleri istenmiştir. Bu ünitede Z, Ç ve G harfleri öğretilmiştir.

\section{9. Ünite}

"Kursta" başlığını taşıyan dokuzuncu ünitede "ad, soyadı, adres, sokak, mahalle, memur, görevli, form” sözcükleri yeni sözcükler olarak verilmiştir. Bu bölümde "Adınız ne?" "Nerede otuyorsunuz?" soru kalıpları verilmiştir. $\mathrm{Bu}$ ünitede Ş, $\mathrm{C}$ ve $\mathrm{P}$ harflerinin öğretimi gerçekleş̧irilmiştir. Ünitenin on sekizinci etkinliğinde ad, soyadı, doğum tarihi, doğum yeri ve adres bilgilerinin yer aldığı bir form verilmiş, öğrenicilerin bu formu okumaları ve bu formla ilgili konuşmaları istenmiştir. Bu etkinliği, iki dinleme etkinliği takip etmektedir. Söz konusu dinleme etkinliklerinde öğretilen söz varlığına dair bilgilerin doldurulması istenmiştir. Ünitenin yirmi ikinci ve yirmi üçüncü etkinlikleri yazma becerisini geliştirmeye ayrılmıştır.

\section{0. Ünite}

Kitabın onuncu ünitesi "Renkler" başlığını taşımaktadır. Ünitede yeni sözcükler olarak renk adları verilmektedir. Bu ünitede "Vazo ne renk?" ve "En sevdiğin renk ne?" soru kalıplarının öğretimi amaçlanmıştır. H, V, F ve J harfleri öğretilmiştir. Öğrenicilerden renkleri yazmaları ve harfleri eksik verilen sözcükleri tamamlamaları istenmiştir. Ünitenin yirmi ikinci etkinliğinde; öğrenicilerin görsellerle sözcükleri eşleştirmeleri istenmiş, yirmi üçüncü etkinlikte ise öğrenicilerden yirmi ikinci etkinlikte yer alan görsellerin renklerini yazmaları istenmiştir. Ünitenin yirmi dördüncü ve yirmi beşinci etkinliği dinleme çalışmasına ayrılırken ünitenin son etkinliği görselde yer alan nesnelerin renklerinin belirtilmesini isteyen bir konuşma etkinliğidir.

\section{1. Ünite}

"Saatler" başlı̆̆ını taşıyan on birinci ünitede saatlerin söylenmesi amaçlanmıştır. Yeni sözcükler olarak saatlerin söylenmesine yönelik kalıplara yer verilmiş ve "Saat kaç?" "Saat kaçta?" "Ne zaman?" soru kalıplarının öğretimi gerçekleştirilmiştir. Bu ünitede Ğ harfi öğretilmiştir. Öğrenicilerin etkinlikte verilen sayıları yazmaları istenmiştir. On birinci ünitenin dokuzuncu ünitesinden itibaren saat görsellerinin yer aldığı etkinliklerde öğrenicilerin saatleri söylemeleri ve yazmaları istenmiştir. Kitabın on altıncı etkinliğinde "Ne zaman geliyor?" soru kalıbı verilmiş, öğrenicilerden etkinlikte geçen saatleri dinleyerek cümleleri tamamlamaları istenmiştir. Ünitenin on sekizinci etkinliği yerleri karışık bir şekilde verilen sözcükleri doğru yere koyarak cümle kurmalarını sağlamak üzere hazırlanmıştır. Ünitenin son etkinliği, saatlerin kullanımına yönelik diyalog geliştirmeyi hedefleyen bir konuşma etkinliğidir. 


\section{2. Ünite}

On ikinci ünite "Günler ve Aylar" başlığını taşımaktadır. Bu ünitede, yeni sözcükler olarak günler ve aylar verilmiştir. Ünitede "Bugün ne?", "Parti hangi gün?" "Hangi günler tatil?" "Nisanda hava nasıl?" gibi soru kalıplarına yer verilmiştir. Ünitede, mevsimlerin ve ayların öğretimi yapılmıștır. "Hangi ayda doğdun?" soru kalıbı verilmiştir. Ünitenin son etkinliğinde öğrenicilerden görseldeki resimleri kullanarak ne zaman, ne yaptıklarını yazmaları istenmiştir.

\section{3. Ünite}

On üçüncü ünite "Alışveriş" başlığını taşımaktadır. Ünitenin yeni sözcükleri; "sebze, meyve, elma, muz, çilek, patates ve domates" olarak verilmiştir. "Ne istiyorsunuz?", "Ne kadar?" soru kalıpları ünitede öğretilmesi hedeflenen kalıplardandır. Ünitede hedeflenen diğer bir kazanım ise öğrenicilerin iki basamaklı sayıları okuyup yazabilmeleri ve bu sayıları dinlediklerinde anlayabilmeleridir. Ünitenin yirminci etkinliği "Kaç yaşındasın?" soru kalıbının anlaşılıp cevap verilmesine yönelik olarak hazırlanmıştır. Ünitede yer alan daha sonraki etkinlik, öğrenicilerin telefon numarasını anlayıp söyleyebilmeleri için hazırlanmıştır.

\section{4. Ünite}

On dördüncü ünite, "Kıyafetler" başlığını taşımaktadır. Ünitede öğretilmesi hedeflenen yeni sözcükler "kazak, etek, elbise, tişört, pantolon, gömlek, ceket, şort, ayakkabı, adam, kadın, çocuk, uzun saçl1-kısa saçlı, uzun boylu-kısa boylu, yaşlı-genç, şişman-zayıf, sarı-kahverengi-siyah-beyaz saç" şeklindedir. Ünitede alışverişle ilgili bir diyaloğa yer verilmiştir. Bu ünitede, insanların birbirlerini tarif edebilecekleri kalıplara yer verilmiştir. Ünitede ayrıca alışveriş merkezlerinde yer alan uyarı işaretlerinin anlamları, bu işaretlerin görsellerle eşleştirilmesi de öğrenicilere kazandırılması gereken bir kazanım olarak görülmektedir. Ünitenin son etkinliği "Afiyet olsun, geçmiş olsun, kolay gelsin, hayırlı olsun" kalıplarının öğretimi üzerinedir.

\section{5. Ünite}

"Bir Günüm" başlığını taşıyan on beşinci ünitede, günlük rutinle ilgili sözcüklere yer verilmiştir. Ünitede "Bir günde neler yapıyorsun?" soru kalıbının öğretilmesi hedeflenmiş, ünitedeki günlük aktiviteler görsellerle verilmiştir. Ünitenin son etkinliği bir konuşma etkinliğidir. $\mathrm{Bu}$ etkinlikte öğrenicilerin "Nerede oturuyorsun?" soru kalıbına cevap vermeleri istenmiştir.

\section{6. Ünite}

"Boş Zamanım" başlıklı on altıncı ünitede "futbol oynamak, kitap okumak, müzik dinlemek, dans etmek, resim yapmak" gibi kalıpların öğretimi amaçlanmıştır. Şimdiki zamanda olumlu ve olumsuz cümleler sezdirme yöntemi ile kazandırılmak istenmiştir. Ünitede kişi zamirleri verilmiş, kişi zamirlerine göre şimdiki zamanda cümle kalıplarının eşleştirilmesi istenmiştir. Ünitenin son etkinliği dinleme çalışmasıdır. Öğrenicilerin dinlediklerini boş bırakılan metinde yazmaları istenmiş̧ir. On beşinci ve on altıncı ünitelerin öğrenicilerin günlük aktivitelerini ve rutinlerini ifade edebilme noktasında yabancı dil öğretiminde yakından uzağa ilkesine uygun olarak hareket ettiği tespit edilmektedir.

\section{Arapça Bölümü}

On altıncı üniteden sonra kitabın Arapça bölümü başlamaktadır. Kitabın Arapça bölümü, Türkçe bölümünde yer alan konulara paralel bir şekilde hazırlanmış, öğrenicilerin öğrendikleri yapıları karşılaştırması sağlanmıştır. Bu anlamda alan yazında yer alan iki dilli okuma kitaplarından farklı olarak ikinci dilin ayrı bir bölüm olarak yer aldı̆̆ı görülmektedir.

\section{SONUÇ VE ÖNERILER}

"İlk Adım Türkçeyi Yabancı Dil Olarak Öğrenen Yetişkinler İçin Türkçe-Arapça Çift Alfabeli İlk Okuma-Yazma Kitabı" adlı kitabın yabancı öğrenicilere Türkçe öğretmek için hazırlanan Türkçe öğretim setlerinden farklı bir amaca hizmet ettiği, iki dilli bir kitap olduğu, öğrenicilere okuryazarlık kazandırmayı amaçladığı görülmektedir. Bu hâliyle kitabın yabancı dil olarak Türkçe öğretiminde Latin alfabesinin öğretilmesi noktasında yaşanan sorunları gidermede, Suriyeli öğreniciler özelinde alfabe 
farklılığından kaynaklı sorunlar yaşayan öğrenicilerin ihtiyaçlarını karşılama noktasında faydalı bir olacağı düşünülmektedir.

Şu anda Türkiye'de ve yurt dıșında yabancı öğrencilere Türkçe öğretmek için çeşitli Türkçe öğretim setleri kullanılmaktadır. Ankara Üniversitesi TÖMER'in hazırlamış olduğu Yeni Hitit Yabancılar için Türkçe Öğretim seti, yabancı öğrenicilere Türkçe öğretmek için kullanılmakta olan öğretim setlerinden biridir. Ankara Üniversitesi TÖMER'in hazırladığı bu iki kitap; "İlk Adım Türkçeyi Yabancı Dil Olarak Öğrenen Yetişkinler İçin Türkçe-Arapça Çift Alfabeli İlk Okuma-Yazma Kitabı" ve "Yeni Hitit Yabancılar için Türkçe Öğretim Setleri” karşılaştırıldığında şu bilgiler elde edilebilir:

Tablo 3: Yeni Hitit Yabancılar İçin Türkçe A1-A2 Kitabı ve İlk Adım Türkçeyi Yabancı Dil Olarak Öğrenen Yetişkinler İçin Türkçe-Arapça Çift Alfabeli İlk Okuma-Yazma Kitabının Karşılaştırılması

\begin{tabular}{|c|c|c|}
\hline Kitapların Özellikleri & $\begin{array}{c}\text { Yeni Hitit Yabancılar için Türkçe Öğretim } \\
\text { Seti }\end{array}$ & $\begin{array}{l}\text { İlk Adım Türkçeyi Yabancı Dil Olarak } \\
\text { Öğrenen Yetişkinler İçin Türkçe-Arapça } \\
\text { Çift Alfabeli İlk Okuma-Yazma Kitabı }\end{array}$ \\
\hline Ünite Sayısı & $\begin{array}{l}12 \text { üniteden oluşmaktadır. Her ünite } 3 \text { modüle } \\
\text { ayrılmıştır. }\end{array}$ & $\begin{array}{l}16 \text { üniteden oluşmaktadır. Kitap modüllere } \\
\text { ayrılmamıştır. }\end{array}$ \\
\hline $\begin{array}{l}\text { Becerilere } \\
\text { Etkinlikler }\end{array}$ & $\begin{array}{l}\text { Dört temel becerinin geliştirilmesine ve dil } \\
\text { bilgisi ögretimine yönelik etkinlikler } \\
\text { bulunmaktadır. }\end{array}$ & $\begin{array}{l}\text { Dört temel becerinin geliştirilmesine ve dil } \\
\text { bilgisi öğretimine yönelik etkinlikler } \\
\text { bulunmakla beraber okuma ve yazma } \\
\text { öğretimine ağırlık verilmiştir. }\end{array}$ \\
\hline Dil bilgisi Öğretimi & $\begin{array}{l}\text { Dil bilgisi konuları tablolar hâlinde verilmiş } \\
\text { ve boşluk doldurma etkinlikleriyle } \\
\text { pekiştirilmiştir. }\end{array}$ & $\begin{array}{l}\text { Dil bilgisi konuları sezdirme yoluyla } \\
\text { verilmiştir. Dil bilgisi tabloları kitapta yer } \\
\text { almamıştır. }\end{array}$ \\
\hline Dinleme Etkinlikleri & $\begin{array}{l}54 \text { adet dinleme etkinliği bulunmaktadır. } \\
\text { Üniteler okuma, dinleme ya da görsellerden } \\
\text { hareketle konuşma etkinlikleri ile } \\
\text { başlamaktadır. }\end{array}$ & $\begin{array}{l}101 \text { adet dinleme etkinliği bulunmaktadır. } \\
\text { Her ünite dinleme etkinliği ile başlamaktadır. }\end{array}$ \\
\hline Okun & 58 adet okuma etkinliği bulunmaktadır. & 100 adet okuma etkinliği bulunmaktadır. \\
\hline Yazma Etkinlikleri & $\begin{array}{l}27 \text { adet paragraf ya da kompozisyon yazma } \\
\text { becerisine yönelik yazma etkinliği } \\
\text { bulunmaktadır. }\end{array}$ & $\begin{array}{l}128 \text { adet harf yazma, cümle ve form } \\
\text { tamamlama, paragraf yazma } \\
\text { bulunmaktadır. }\end{array}$ \\
\hline Konuşma Etkinlikleri & $\begin{array}{l}46 \text { adet konuşma etkinliği bulunmaktadır. } \\
\text { Konuşma etkinlikleri sözlü anlatım ve } \\
\text { karşılıklı konuşma olarak hazırlanmıştır. }\end{array}$ & $\begin{array}{l}33 \text { adet konuşma etkinliği bulunmaktadır. } \\
\text { Konuşma etkinlikleri sözlü anlatım ve } \\
\text { karşıllılı konuşma olarak hazırlanmıştır. }\end{array}$ \\
\hline Çalışma Kitabı & $\begin{array}{l}\text { Çalışma kitabı } 12 \text { üniteden oluşmaktadır. Her } \\
\text { ünite } 3 \text { modüle ayrılmıştır. Dört temele } \\
\text { beceriye yönelik etkinlikler yer almaktadır. }\end{array}$ & $\begin{array}{l}\text { Kitabın çalışma } \\
\text { bulunmamaktadır. }\end{array}$ \\
\hline
\end{tabular}

İncelenen kitap, yabancı dil olarak Türkçe öğretiminde kullanılan diğer Türkçe öğretim setleri ile temalar açısından karşılaştırıldığında ise şu bilgilere ulaşılabilir: 
Tablo 4: İlk Adım Türkçeyi Yabancı Dil Olarak Öğrenen Yetişkinler İçin Türkçe-Arapça Çift Alfabeli İlk Okuma-Yazma Kitabının Diğer Türkçe Öğretim Setleri ile Temalar Açısından Karşılaştırılması

\begin{tabular}{|c|c|c|c|c|}
\hline $\begin{array}{c}\text { Yeni İstanbul } \\
\text { Uluslararası } \\
\text { Öğrenciler için } \\
\text { Türkçe Ders Kitabı } \\
\text { A1 Seviyesi }\end{array}$ & $\begin{array}{c}\text { Gazi Üniversitesi } \\
\text { Yabancılar için } \\
\text { Türkçe Öğretim Seti } \\
\text { A1 Seviyesi }\end{array}$ & $\begin{array}{c}\text { Yedi İklim Türkçe } \\
\text { Öğretim Seti A1 } \\
\text { Seviyesi }\end{array}$ & $\begin{array}{c}\text { İlk Adım Türkçeyi } \\
\text { Yabancı Dil Olarak } \\
\text { Öğrenen Yetişkinler } \\
\text { İçin Türkçe-Arapça } \\
\text { Çift Alfabeli İlk } \\
\text { Okuma-Yazma } \\
\text { Kitabı } \\
\end{array}$ & $\begin{array}{l}\text { Yeni Hitit Yabancılar için } \\
\text { Türkçe Ders Kitabı A1-A2 }\end{array}$ \\
\hline $\begin{array}{ll}\text { 1. } & \text { Merhaba } \\
\text { 2. } & \text { Nerede? } \\
\text { 3. } & \text { Ne } \\
& \text { yapıyorsun } \\
& ? \\
\text { 4. } & \text { Benim } \\
& \text { Dünyam } \\
\text { 5. } & \text { Zaman } \\
& \text { Zaman } \\
\text { 6. } & \text { Çevremiz } \\
& \text { ve Biz }\end{array}$ & $\begin{array}{ll}\text { 1. } & \text { Merhaba } \\
\text { 2. } & \text { Nerede, Ne } \\
& \text { zaman, } \\
\text { Nasil? } \\
\text { 3. } \\
\text { 4. } \\
\text { Dikkat } \\
\text { Teknik } \\
\text { İşlemler } \\
\text { 5. } & \text { Nasil } \\
& \text { Giderim? } \\
\text { 6. İletişim } \\
\text { Kuruyorum }\end{array}$ & $\begin{array}{ll}\text { 1. } & \text { Tanışma } \\
\text { 2. } & \text { Ailemiz } \\
\text { 3. } & \text { Günlük } \\
& \text { Hayat } \\
\text { 4. } & \text { Çevremiz } \\
\text { 5. } & \text { Meslekle } \\
& \text { r } \\
\text { 6. } & \text { Ulaşım } \\
\text { 7. } & \text { İletişim } \\
\text { 8. } & \text { Tatil }\end{array}$ & $\begin{array}{ll}\text { 1. } & \text { Merhaba } \\
\text { 2. } & \text { Ailem } \\
\text { 3. } & \text { Evim } \\
\text { 4. } & \text { Sayılar } \\
\text { 5. } & \text { Sokakta } \\
\text { 6. } & \text { Nasılsın? } \\
\text { 7. } & \text { Ne } \\
& \text { Yiyoruz? } \\
& \text { Ne } \\
& \text { İçiyoruz? } \\
\text { 8. } & \text { Meslekler } \\
\text { 9. } & \text { Kursta } \\
\text { 10. } & \text { Renkler } \\
\text { 11. } & \text { Saatler } \\
\text { 12. } & \text { Günler ve } \\
& \text { Aylar } \\
\text { 13. } & \text { Alışveriş } \\
\text { 14. } & \text { Kiyafetler } \\
\text { 15. } & \text { Bir Günüm } \\
\text { 16. } & \text { Boş } \\
& \text { Zamanım }\end{array}$ & $\begin{array}{ll}\text { 1. } & \text { Merhaba } \\
\text { 2. } & \text { Günlük Hayat } \\
\text { 3. } & \text { Yakın Çevremiz } \\
\text { 4. } & \text { Zaman Geçiyor } \\
\text { 5. } & \text { Afiyet Olsun } \\
\text { 6. } & \text { Bürokrasi Her } \\
& \text { Yerde } \\
\text { 7. } & \text { Gelecek de Bir } \\
& \text { Gün Gelecek } \\
\text { 8. } & \text { Rivayet Odur } \\
& \text { Ki... } \\
\text { 9. } & \text { Farklı Dünyalar } \\
\text { 10. } & \text { Medya } \\
\text { 11. } & \text { Sağlıklı Yaşam } \\
\text { 12. } & \text { Yolculuk }\end{array}$ \\
\hline
\end{tabular}

Tablo 4’ten de görüleceği üzere yabancı dil olarak Türkçe öğretimi üzerine hazırlanan mevcut ders kitapları incelendiğinde A1 seviyesinde malzemeler geliştirildiği, her ders kitabının tanışma diyalogları ile başladığı, yakından uzağa ilişkisi ile temaların verildiği görülmektedir. Ünite sayıları değişse de tüm ders kitaplarının CEFR'de belirlenen ölçütlere göre dört temel beceri dikkate alınarak hazırlandığı bu nedenle temaların birbiriyle ile ilişkili olduğu görülmektedir. "İlk Adım Türkçeyi Yabancı Dil Olarak Öğrenen Yetişkinler İçin Türkçe-Arapça Çift Alfabeli İlk Okuma-Yazma Kitabı"nın ise A1 öncesi seviyeye yönelik olarak hazırlandığı ve kitapta yer alan kazanımların CEFR (2020)'de A1 öncesi seviyedeki "Klsa, çok basit soruları ve ifadeleri yavaş söylendiği, görseller ve beden diliyle desteklendiği takdirde anlayabilir. Açık ve yavaş bir şekilde iletilmeleri koşuluyla, günlük, tanıdık kelimeleri / işaretleri, basit talimatları anlayabilir. Haftanın günlerini, sayılarını, fiyatları, tarihleri yavaş söylendiğ takdirde anlayabilir." paralel olduğu tespit edilmektedir. Aynı şekilde incelenen kitabın A1 öncesi okuryazarlık öncesi ve okuryazar olmayanlara yönelik hazırlanan A1 öncesi Başvuru Rehberi'ndeki okuma becerisine yönelik "Sesbilimsel farkındalık geliștirmeye başlar. Ses-yazıbirim ayrımıyla ilgili farkındalık geliştirmeye başlar. Yazı- ses dizgesi ile ilgili farkındalık gelişstirmeye başlar. Yazıbirimleri tanımaya ve okumaya başlar. Bazı sözcükleri ilk bakışta tanımaya başlar." Sözel alımlama becerisine yönelik "Yalın sözcük ve ifadelerin sözlü biçimini ayırt etmeye başlar. Sesbilimsel farkındalık kazanmaya başlar. Soru ezgisini ayırt etmeye başlar. Sözcüklerin başlangıç ve bitişlerini ayırt etmeye başlar. Yazı dili ile konuşma dili farkını ayırt etmeye başlar", sözlü üretim becerisine yönelik "Yeni duyduğu kısa sözcükleri ve ifadeleri tekrar etmeye başlar (merhaba, benim adım...). Yalın tümceleri tekrar etmeye başlar. Tanıdı̆̆ sesleri yeniden üretmeye başlar. Yeni duyduğu kısa sözcükleri ve ifadeleri tekrar etmeye başlar. Ĕger yardim edilirse yalın tümceleri ifade etmeye başlar. Sik duyduğu sesleri üretmeye başlar (ana dili aktarımları eşliğinde). Soru ezgisini kullanmaya başlar (Yarın? Dün? Kaç? Var mı?), yazma becerisine yönelik Yazıbirimi yazllış yönüne uygun olarak yazar. Kısa sözcükleri, seslemleri ve kısaltmaları (al, el, kal, kalk, TV...) kopyalar/ yazmaya başlar/yazar. Yardım edilirse kısa sözcükleri, seslemleri ya da bilindik sözcükleri dinledikten sonra yazmaya başlar/ yazar. Yazıbirimi yazıllş yönüne uygun olarak yazar. Kısa sözcükleri, seslemleri ve kısaltmaları (al, el, kal, kalk, TV...) kopyalar/ yazmaya başlar/ yazar." kazanımları ile de uyumlu olduğu görülmektedir (Polat vd., 2017). Bu hâliyle incelenen kitabın seviye ve hedef kitlenin ihtiyaçları açısından, alan yazındaki Türkçe öğretim setlerinden farklı bir çalışma olduğu tespit edilmektedir. 
Kitap, "Kıyafetler" başlı̆ıını taşıyan ünite adının, ünitede yer alan kalıpları kapsayıcı olmaması noktasında eleştirilebilir. Çünkü ünitede yer alan "Afiyet olsun, geçmiş olsun, kolay gelsin, hayırlı olsun" kalıplarının öğretimi ünitenin adıyla pek uyumlu görülmemektedir. Bu kalıplar başka bir ünitenin içerisinde yer alabilir. Aynı şekilde ünitede, kişilerin fiziksel özelliklerinin verilmesi (uzun saçl1-kısa saçlı, uzun boylu-kısa boylu, yaşlı-genç, şişman-zayıf, sarı-kahverengi-siyah-beyaz saç) ünitenin adından yola çıkıldığında uyumsuz görünmektedir. Bu anlamda kitabın sonraki baskılarında bu ünite için daha kapsayıcı bir isim tercih edilmesi önerilebilir. Kitabın dinleme çalışmalarının CD kullanılarak yapılacak olması öğrenicilere ve öğreticilere zaman zaman zorluk yaşatabilir. Bu noktada son zamanlarda hazırlanan Türkçe öğretim setlerindeki (Yeni İstanbul Uluslararası Öğrenciler İçin Türkçe Ders Kitapları gibi) QR kodu uygulamalarının kitabın yeni baskılarında kullanılması önerilebilir. Ayrıca incelenen kitabın bir çalışma kitabının hazırlanması da öğreniciler için faydalı olabilir. Alan yazında Ömeroğlu (2016), Özdemir ve Kıral (2020) gibi çalıșmalarda kitap yazarlarına çeșitli tavsiyeler verildiği görülmektedir. İncelenen kitap ve alan yazındaki bu öneriler dikkate alındığında teknolojinin gelişmesi, eğitim teknolojisindeki yeniliklerin ve uzaktan eğitim faaliyetlerinin artması sonucunda yabancı öğreniciler için Al öncesinde hazırlanacak ders materyallerinin teknoloji tabanlı öğretim için zenginleştirilmesi önerilebilir.

Sonuç olarak "İlk Adım Türkçeyi Yabancı Dil Olarak Öğrenen Yetişkinler İçin Türkçe-Arapça Çift Alfabeli İlk Okuma-Yazma Kitabı"nın alan yazında A1 öncesi seviye dikkate alınarak okuryazarlık kazandırma amacıyla hazırlandığı ve dört temel becerinin geliştirilmesine yönelik olduğu görülmektedir. Kitabın alan yazında yeni çalışmalara kaynaklık edeceği öngörülmektedir.

\section{KAYNAKÇA}

Altunkaya, H. (2018). Yabancı Dil Olarak Türkçe Öğretiminde Dinleme Eğitimi. International Journal of Languages' Education and Teaching, 6(3), 198-207.

Appelbaum, S. (2011). First French Reader: A Beginner's Dual Language Book. New York: Dover Publications.

Barın, E. (2003). Yabancılara Türkçe Öğretiminde Temel Söz Varlığının Önemi. Türklük Bilimi Araştırmaları Dergisi, 13(1), 311-317.

Barın, E.; Çobanoğlu, Ş.; Ateş, Ş.; Balcı, M. ve Özdemir, C. (Ed.) (2015). Yedi İklim Türkçe A1 Seviyesi. Ankara: Yunus Emre Enstitüsü Yayınları.

Bölükbaş F. ve Yılmaz, M. Y. (Ed.) (2020). Yeni İstanbul Yabancılar İçin Türkçe Ders Kitabı A1. İstanbul: Kültür Sanat Basımevi.

Buz, Y. (2002). Pocket English Grammar. İstanbul: Damla Yayınevi.

CEFR (2020). Common European Framework of Reference for Languages: Learning, Teaching, Assessment Companion Volume with New Descriptors. Fransa: Council of Europe (Avrupa Konseyi).

Çiftçi, Ö. ve Demirci, R. (2019). Alfabe Farklılıklarının Yabancılara Türkçe Öğretimindeki Etkisi. TÜRÜK Uluslararası Dil, Edebiyat ve Halkbilimi Araştırmaları Dergisi, 7(19), 96-127.

Flores, A. (1964). First Spanish Reader: A Beginner's Dual Language Book. New York: Bantam Books.

Karakuzu, M ve Takkaç, M. (Ed.) (2011). Atatürk Üniversitesi Açı̌̈ögretim Fakültesi Yabancı Dil 1-2. Erzurum: Atatürk Üniversitesi Açıköğretim Fakültesi Yayını.

Kıral, B. (2020). Nitel Bir Veri Analizi Yöntemi Olarak Doküman Analizi. Siirt Üniversitesi Sosyal Bilimler Enstitüsü Dergisi, 0(15), 170-189.

Kurt, M. ve Temur, N. (Ed.) (2016). Gazi Üniversitesi Yabancılar için Türkçe A1 Temel Düzey. Ankara: Başak Matbaa.

Kurudayığlu, M. ve Zorpuzan, R. (2018). Yabanc1 Dil Olarak Türkçe Öğretiminde Dinleme Öğretimine Dair Öğretmen Bilişleri. International Journal of Language Academy, 6(3), 179-193.

Melanlığlu, D. (2016). Yabancı Öğreniciler için Dinleme Becerisine Yönelik Üstbilişsel Dereceli Puanlama Anahtarı. Erzincan Üniversitesi Sosyal Bilimler Enstitüsü Dergisi, 18(2), 1206-1229.

Ömeroğlu, E. (2016). Yabancılara Türkçe Öğretimi İçin Hazırlanmış Ders Kitaplarının İncelenmesi, (Yayımlanmamış Doktora Tezi), (Danışman: Prof. Dr. İsmail Güleç), Sakarya: Sakarya Üniversitesi Eğitim Bilimleri Enstitüsü Türkçe Eğitimi Anabilim Dalı Türkçe Eğitimi Bilim Dal1. 
Özdemir, S. ve Kıral, U. (2020). Türkçenin Yabancı Dil Olarak Öğretiminde Kullanılan İstanbul A1 ve A2 Ders Kitaplarının Sorularının İncelenmesi, 4. Uluslararası Sınırsız Eğitim ve Araştırma Seтроzуити (USEAS 2020). https://bit.ly/3z7czys adresinden 15.06.2021 tarihinde erişildi.

Polat, Y.; Köse, D.; Peçenek, D. ve Durmuş A. O. (2017). Yabancı Dil Olarak Türkçe İlk Kazanımları için Başvuru Rehberi A1 Öncesi. Yunus Emre Enstitüsü ve Kurmay. https://bit.ly/3z4Nxjs adresinden 15.06.2021 tarihinde erişildi.

Şengül, K. (2014). Türkçenin Yabancı Dil Olarak Öğretilmesinde Alfabe Sorunu. Uluslararası Türkçe Edebiyat Kültür Ĕgitim Dergisi, 3(1), 325-339.

Uzun, G. L. (Ed.) (2021). İlk Adım Türkçeyi Yabancı Dil Olarak Öğrenen Yetişkinler İçin Türkçe-Arapça Çift Alfabeli Ilk Okuma-Yazma Kitabı. Ankara: Ankara Üniversitesi Basımevi.

Uzun, N. E. (Ed.) (2017). Yeni Hitit Yabancılar için Türkçe Ders Kitabı Temel: A1-A1 Seviyesi. Ankara: Ankara Üniversitesi Basımevi. 